\title{
PERANGKAT LUNAK SIMULASI PESAWAT MELALUI NAVAID
}

\author{
Ariawan D Rachmanto ${ }^{1}$, Hernawati ${ }^{2}$ \\ ${ }^{12}$ Fakultas Ilmu Komputer Informatika Universitas Nurtanio Bandung \\ Jl Pajajaran 219 Lanud Husein Bandung

Abstrak-Menjadi penerbang adalah merupakan cita-cita banyak orang, tetapi banyak kendala yang harus dihadapi yang utama adalah perlu biaya yang besar untuk menjadi seorang pilot. Dikarenakan pendidikan pilot perlu menggunakan peralatan yang mahal seperti praktek terbang menggunakan pesawat terbang. Sebelum melakukan praktek terbang, calon pilot belajar terbang dengan menggunakan simulator pesawat. Dalam penerbangan pilot dapat menggunakan instrument Navaids terletak di darat untuk terbang dari satu bandara ke bandara lainnya, penerbangan menggunakan Navaid divisualisasikan dengan instrument HSI dalam cockpit pesawat. Visualisasi jarum instrument HSI dapat memandu pilot mendekati Navaids yang menjadi tujuan. Penelitian dilakukan dengan membuat perangkat lunak simulasi pesawat mendekati Navaids (VOR dan NDB) dengan menggunakan instrument HSI. Metode pengembangan perangkat lunak menggunakan Metoda Prototype. Hasil perangkat lunak yang dikembangkan dibandingkan dengan perangkat lunak Garmin ternyata hasil visualisasi yang diperoleh adalah sama dengan perangkat lunak pembanding.

Kata Kunci-. HSI, VOR,NDB, Navaid, Airway

Abstract - Becoming a pilot is the dream of many people, but there are many obstacles that must be faced, the main one is that it costs a lot to become a pilot. Because pilot education needs to use expensive equipment such as flying practice using an airplane. Before doing practice flying, prospective pilots learn to fly using an airplane simulator. In flight the pilot can use the Navaids instrument located on the ground to fly from one airport to another, the flight using the Navaid is visualized with the HSI instrument in the aircraft cockpit. The HSI instrument needle visualization can guide the pilot closer to the destination Navaids. The research was conducted by making an aircraft simulation software approaching Navaids (VOR and NDB) using the HSI instrument. The software development method uses the Prototype Method. The results of the developed software compared to the Garmin software, it turns out that the visualization results obtained are the same as the comparison software.

Keywords - . HSI, VOR,NDB, Navaid, Airway

\section{PENDAHULUAN}

Pilot pada saat ini merupakan profesi yang menjanjikan. Banyak orang yang bercita-cita menjadi seorang pilot profesional. Mereka tahu untuk menjadi seorang pilot pesawat diperlukan banyak dedikasi, pengorbanan dan keseriusan dari calon pilot, juga diperlukan biaya tidak sedikit agar dapat mengikuti pendidikan menjadi pilot.v

Menjadi seorang pilot profesional tidak hanya diperlukan biaya besar untuk pendidikan, tetapi juga diperlukan semangat, kerja keras serta komitmen tinggi terhadap profesi yang akan menjadi sumber penghasilan di hari depan.

Dalam pendidikan pilot yang dilakukan di sekolah pilot baik negara maupun swasta selain belajar secara teori juga diperlukan belajar praktek terbang menggunakan pesawat terbang, untuk itu diperlukan biaya yang tidak sedikit, karena sebelum diperkenalkan terbang menggunakan pesawat sebenarnya, seorang calon pilot harus belajar teori dalam kelas dengan diperkenalkan cara kerja dari instrument pesawat terbang dan cara menggunakan instrumen tersebut, jika secara teori sudah cukup baru terbang dengan menggunakan simulator pesawat sebelum praktek terbang dengan menggunakan pesawat sebenarnya.

Di udara pesawat terbang untuk terbang dari satu bandara ke bandara lainnya dapat dilakukan dengan terbang secara visual (VFR atau Visual Flight Rule), yaitu terbang dengan mengandalkan tanda-tanda alam yang terdapat di darat, seperti gunung, pantai, sungai, bangunan dapat bangunan gedung atau monumen dll. Selain terbang secara visual dapat dilakukan terbang instrument (IFR atau Instrument Flight Rule). Terbang IFR adalah terbang menggunakan alat navigasi (Navaids) yang terdapat di bumi atau daratan, seperti VOR/DME, NDB, ILS Marker Beacon (Midle Marker, Inner Marker dan Outer Marker). Seperti halnya didarat, diudara juga terdapat airways dan intersection dengan demikian pilot dapat terbang sampai bandara tujuan. 


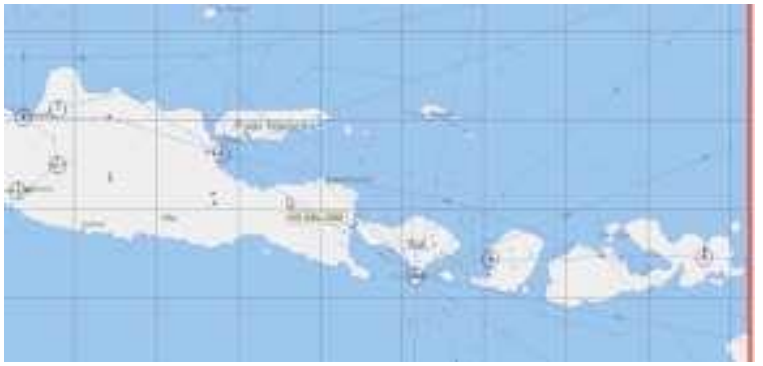

Gbr. 1 Peta Penerbangan Jeppesen

Gambar 1 merupakan peta penerbangan Jeppesen dengan airway, intersection, VOR, $N D B$, airport yang biasa digunakan pilot. Airway adalah lintasan atau jalur penerbangan, terdapat low airway dan high airway. Airway menghubungkan enrout intersection atau terminal intersections. Awal dari akhir sebuah airway dapat airport atau navaid (VOR dan NDB). Sebelum melakukan penerbangan pilot harus membuat perencanaan terbang (flight plan) dengan menggunakan peta Jeppesen pilot mudah untuk membuat flight plan (perencanaan terbang) dimana isi dari flight plan adalah airport asal dan airport tujuan, melalui waypoint atau navaid dalam hal ini VOR dan NDB, ketinggian dan kecepatan yang digunakan.

Ketika akan melalui navaid yang akan dilalui pilot akan melakukan tune frekwensi dari navaid tersebut, sehingga pilot dapat terbang tepat melewati navaid. Dengan adanya panduan navaid sebagai navigasi udara pesawat dapat selamat sampai airport tujuan.

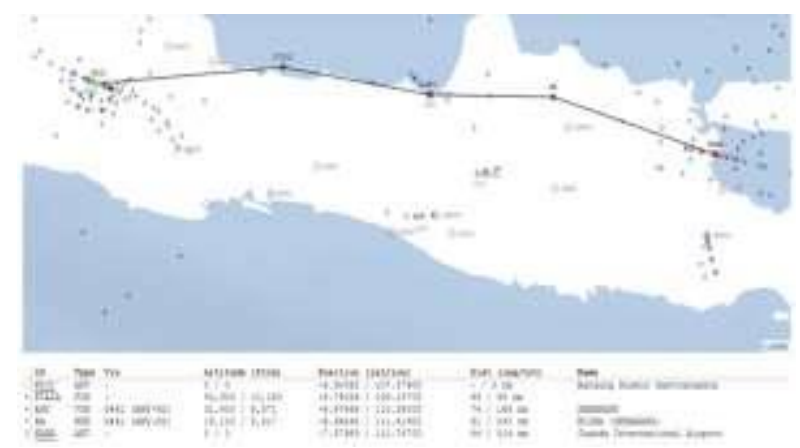

Gbr. 2 Flight Plan dari WICC(Bandung) ke WARR (Surabaya) [8]

Gambar 2 flight plan dari WICC (Bandung) ke WARR (Surabaya). dengan menggunakan airway PIALA sampai VOR ANY, setelah mencapai VOR ANY dengan menggunakan airway G61-W45 sampai mencapai NDB BA (Blora), setelah melewati BA masih menggunakan airway G61-W45 sampai NDB WR atau airport WARR dengan sudut bearing dari WICC ke PIALA adalah $86^{\circ}$, pesawat terbang dari WICC supaya sampai PIALA harus mengarahkan heading $86^{\circ}$. Heading adalah arah terbang pesawat (nose) yang dihitung berdasarkan kutub utara, sedangkan bearing adalah sudut antara nose pesawat dengan navaids.

\section{METODE PENGEMBANGAN}

Metode pengembangan perangkat lunak menggunakan prototype dengan terlebih dahulu membandingkan dengan perangkat lunak yang sudah ada. Secara fungsi awal pesawat mulai terbang dapat diatur sesuai dengan keinginan user, demikian juga navaid yang menjadi arah terbang dapat dipilih. Data airport dan navaid (VOR dan NDB) disimpan dalam file excel sebagai database yang dapat diupdate. Data navaid pada file excel data Indonesia, untuk data airport beberapa airport di Indonesia. Data navaid berupa Nama Navaids, ID Navaids (VOR 3 huruf NDB 2 huruf), latitude, longitude, elevation, frekuensi dan range. Data airport yang disimpan pada file excel berupa Id Airport (4 huruf) Nama Airport, latitude, longitude, elevasi.

Fasilitas navigasi NDB terpasang di darat, NDB memancarkan informasi dalam bentuk signal radio ke segala arah kemudian diterima pesawat terbang yang dilengkapi dengan loop antena, sehingga penerbang dapat menentukan posisinya menuju stasiun NDB yang ditentukan. Peralatan $N D B$ bekerja pada frekuensi antara $190 \mathrm{KHz}$ - $535 \mathrm{KHz}$, data yang dihasilkan dari NDB/ADF berupa jarak dan bearing, NDB dinyatakan dengan code yang terdiri dari 2 huruf (karakter) seperti SO untuk NDB/ADF Solo. NDB selain mempunyai frekwensi juga dinyatakan dalam kode yang ditampilkan pada instrumen, kode NDB terdiri dari 2 huruf[1].

Peralatan navigasi udara lain adalah VOR(VHF Omni-directional Range) biasanya berpasangan dengan DME (Distance Measuring Equipment), bekerja pada frekwensi $108-118 \mathrm{MHz}$, VOR memberikan sinyal panduan ke segala arah dengan azimuth dari 0 sampai 360 derajat, terhadap lokasi stasiun VOR. Selain frekwensi VOR dalam instrumen HSI ditampilkan dengan 3 huruf kode VOR.

VOR bekerja pada frekwensi VHF, maka jangkauan peralatan ini sangat ditentukan atau terbatas oleh "line of sight", oleh sebab itu VOR sebagai alat bantu navigasi jarak pendek yaitu maksimum $\pm 200 \mathrm{~nm}$ pada ketinggian 35.000 feet[2]. VOR merupakan salah satu peralatan navigasi udara yang membantu navigasi pesawat terbang dalam berlalu lintas (Enroute), juga sebagai alat navigasi pesawat ketika mendekati bandara (Approach). Pada waktu posisi pesawat mendekati VOR/DME tujuan, instrument dalam pesawat akan memberikan visualisasi data bearing, slant range (jarak miring) pesawat terhadap VOR/DME[3].

Perangkat lunak simulasi pesawat melewati navaid memvisualisasikan instrumen HSI (Horizontal Situation Indicator) yang terpasang dalam cockpit pesawat. Stasiun $V O R$ dan $N D B$ diletakkan sedemikian rupa di darat lokasi nya berdekatan dengan bandara, Peralatan navigasi digunakan untuk menuntun pesawat supaya dapat sampai tujuan dengan menggunakan cara terbang instrument ${ }^{8)}$. Informasi terbang menggunakan HSI diperoleh visualisasi hasil pengukuran bearing, 
course, jarak pesawat terhadap peralatan navigasi terpasang. Pada perangkat lunak yang dikembangkan VOR/DME dan NDB diletakkan sebaimana seperti yang terdapat pada peta penerbangan, dengan latitude dan longitude sebagaimana mestinya.

Page | 135

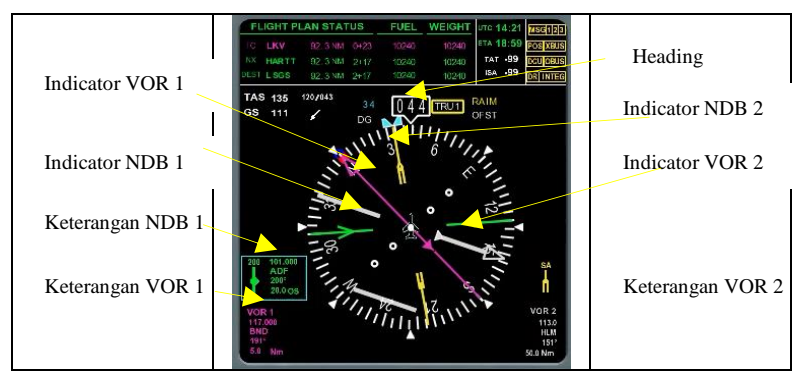

Gbr. 3 Instrument HSI

Gambar 3 model instrument HSI yang digunakan dalam pengembangan perangkat lunak dari Disti GL Studio. Instrument HSI secara umum sudah disediakan, sehingga dapat diintegrasikan dengan microsoft visual studio menggunakan bahasa pemrograman C\#. Dengan memberikan nilai variabel bearing, deviation course dan keterangan lainnya data-data tersebut akan divisualisasikan pada instrumen HSI[4].

Dalam perangkat lunak yang dikembangkan terdapat map (peta) untuk visualisasi pergerakan pesawat. menggunakan map info mapx dengan data airport, navaid dan airway. Data pada map tidak dapat diubah letaknya karena data tersebut sesuai dengan lokasi navaid. Latitude adalah garis yang horisontal / mendatar. Titik $0^{0}$ menunjukkan khatulistiwa, tanda + menunjukkan arah ke atas menuju kutub utara, sedangkan tanda minus di koordinat Latitude menuju ke kutub selatan, nilai latitude adalah $0 \quad-90^{\circ}$ Longitude adalah garis bujur. Garis horizontal mulai dari khatulistiwa. Sudut 0 (Greenwich) ke arah Hawai adalah $0-180^{\circ}$, sedangkan kebalikannya dari 0 ke $-180^{\circ}$

Dengan memodel kan letak menggunakan koordinat latitude dan longitude dapat diletakkan posisi airport dan navaid sesuai dengan letak di bumi. Model map yang digunakan dalam visualisasi pergerakan pesawat terbang seperti berikut:

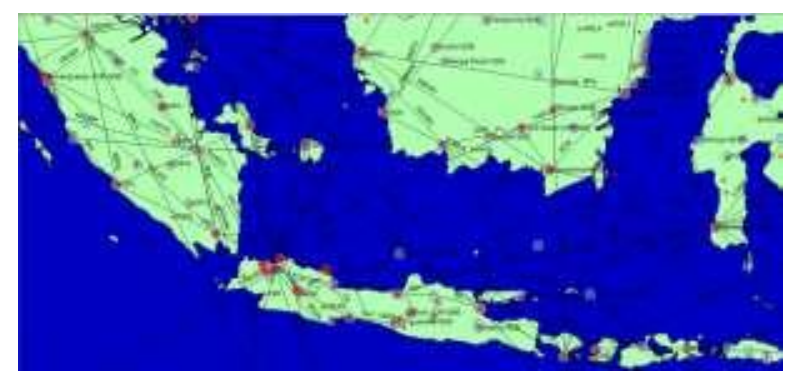

Gbr. 4 Pemodelan Map Indonesia Dengan Airport, Airways dan Navaids

Gambar 4 pemodelan map dengan letak airport, navaid, airways sebagaimana mestinya dapat memvisualisasikan pergerakan pesawat mendekati dan melewati navaid. Dengan memperhatikan jarum pada HSI user dapat memandu pergerakan pesawat supaya tepat pada navaid yang menjadi tujuan sesuai dengan flight plan yang sudah direncanakan.

Perangkat lunak yang dikembangkan dapat mensimulasikan pergerakan pesawat mendekati dan melewati navaids. Pesawat bergerak sesuai dengan variabel heading yang diberikan. Pesawat diskenariokan terbang dari suatu airport dengan latitude dan longitude sudah ditentukan, navaid tujuan pesawat terbang dengan latitude dan longitude sesuai dengan letak di bumi. Dengan latitude dan longitude yang ada dapat dihitung nilai jarak, bearing [5],

$$
\begin{aligned}
& \text { jarak }=\operatorname{acos}(\sin (\text { lat } 1) * \sin (\text { lat } 2)+ \\
& \cos (\text { lat } 1) * \cos (\text { lat } 2) * \cos (\text { lon } 1-\text { lon } 2))
\end{aligned}
$$

Sudut antara pesawat dengan navaids (bearing) dihitung menggunakan persamaan berikut,

$$
\begin{aligned}
& \text { bearing } \\
& =2 \pi-\operatorname{acos}\left(\frac{\sin (\text { lat } 2)-\sin (\text { lat } 1) * \cos (\text { jarak })}{\sin (\text { jarak }) * \cos (\text { lat } 1)}\right)
\end{aligned}
$$

Jika $\sin (\operatorname{lon} 2-\operatorname{lon} 1)<0$

$$
\begin{aligned}
& \text { bearing } \\
& =\operatorname{acos}\left(\frac{\sin (\text { lat } 2)-\sin (\text { lat } 1) * \cos (\text { jarak })}{\sin (\text { jarak }) * \cos (\text { lat } 1)}\right)
\end{aligned}
$$

Pesawat bergerak dengan kecepatan tertentu tiap detik dipengaruhi oleh kecepatan dan arah angin (wind speed dan wind direction), latitude dan longitude pada detik berikutnya dapat dihitung dengan menggunakan :

$G S=\sqrt{A S^{2}+W S^{2}-2 A S * W S * \operatorname{Cos}(\text { heading }-W D)}$

Latitude dan longitude yang baru dapat dihitung menggunakan persamaan,

$$
\begin{gathered}
\operatorname{lat}_{\text {new }}=\operatorname{asin}(\sin (\text { lat } 1) * \cos (\text { jarak })+ \\
\cos (\text { lat } 1) * \sin (G S) * \cos (\text { heading }))
\end{gathered}
$$

$\operatorname{lon}_{\text {new }}=\bmod ($ lon $1-\operatorname{asin}(\sin ($ h eading $) * \sin (\mathrm{GS})) /$

$\cos ($ lat 1$))+\pi, 2 *(\pi)-(\pi))$

Dimana :

lat1 = latitude 1 , latitude pesawat.

lon 1 = longitude 1 , longitude pesawat.

lat2= latitude 2 , latitude VOR.

lon2 = longitude 2 , longitude VOR

$G S=$ Ground Speed

AS = Air Speed

$W S=$ Wind Speed 
WD $=$ Wind Direction

Heading dalam radian

Dengan persamaan-persamaan diatas dapat dibuat alur program sebagai berikut :

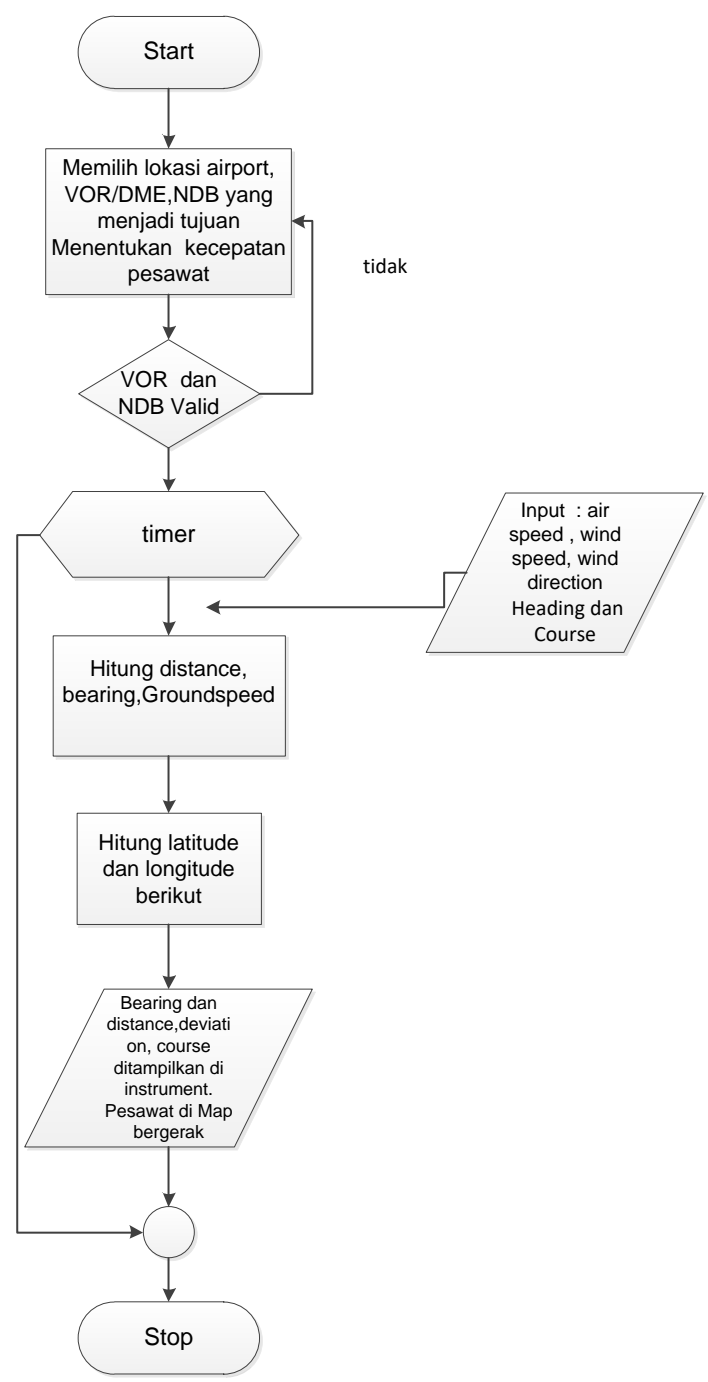

Gbr 5. Flowchart Perangkat Lunak Simulasi Pesawat Melalui VOR dan NDB

Perancangan arsitektur perangkat lunak terdiri dari,

- Map untuk visualisasi pesawat terbang mendekati VOR dan NDB.

- Posisi pesawat pada detik berikutnya berdasarkan perhitungan.

- Instrumen HSI untuk visualisasi pergerakan pesawat terbang dengan informasi heading, bearing, course deviation, data VOR, data NDB.

- Tombol untuk mengatur heading, wind speed dan wind direction.

Dengan data-data diatas perancangan arsitektur perangkat lunak seperti pada gambar berikut.

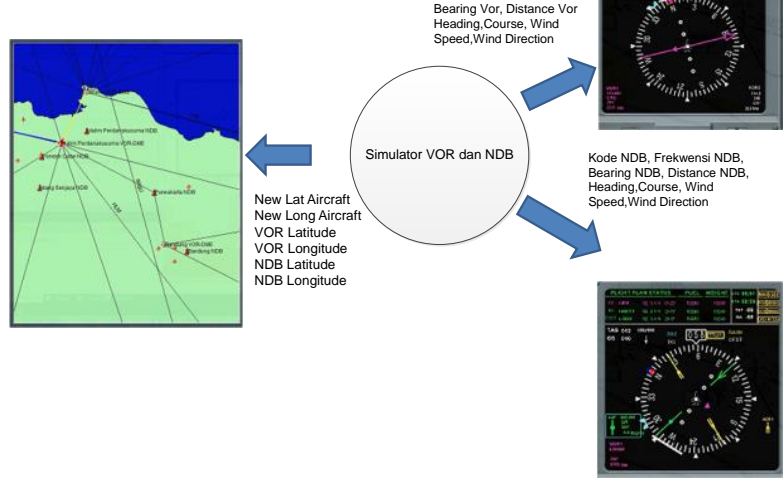

Gbr 6. Arsitektur Perangkat Lunak Simulasi Pesawat Melalui VOR dan NDB

\section{HASIL DAN PEMBAHASAN}

Hasil pengujian dan perhitungan dari perangkat lunak yang dikembangkan dibandingkan dengan perangkat lunak Garmin Integrated Flight Deck Trainer, Version 14.01 Garmin Ltd untuk validasi visualisasi bearing dan course VOR pada instrumen HSI dan menggunakan MapSource Version 6.16.3 Garmin Ltd. Perangkat lunak MapSource Version 6.16.3 Garmin Ltd diperlukan untuk membandingkan hasil perhitungan bearing dan distance yang diperoleh dari hasil perhitungan NDB.

Map pergerakan pesawat dalam perangkat lunak yang dikembangkan dibandingkan dengan Jepessen FliteStar seperti pada gambar berikut.

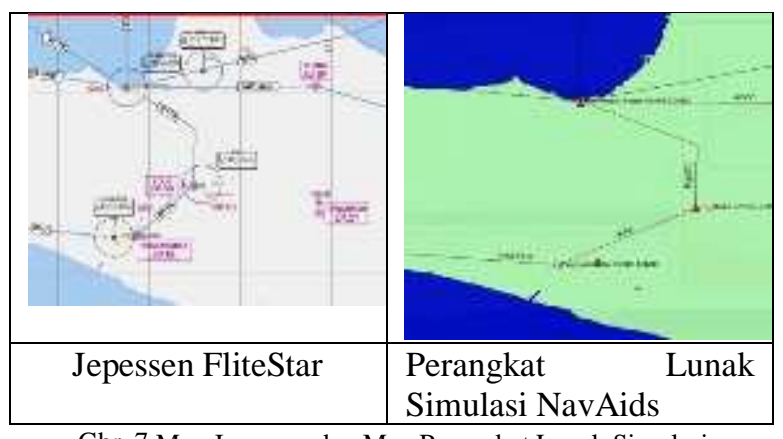

Gbr. 7 Map Jepessen dan Map Perangkat Lunak Simulasi

Jepessen Flite Star merupakan map biasa digunakan dalam penerbangan yang menjadi rujukan pilot. Map perangkat lunak dikembangkan adalah map yang digunakan untuk visualisasi pergerakan pesawat.

Diskenariokan pesawat terbang dari bandara Sultan Mahmud Badaruddin Palembang (WIPP) dengan mengambil arah JMB VOR (Jambi) dan PKP VOR (Pangkal Pinang). Dari Sultan Mahmud Badaruddin dengan heading $0^{0}$ hasil perangkat lunak yang dikembangkan seperti pada gambar berikut. 


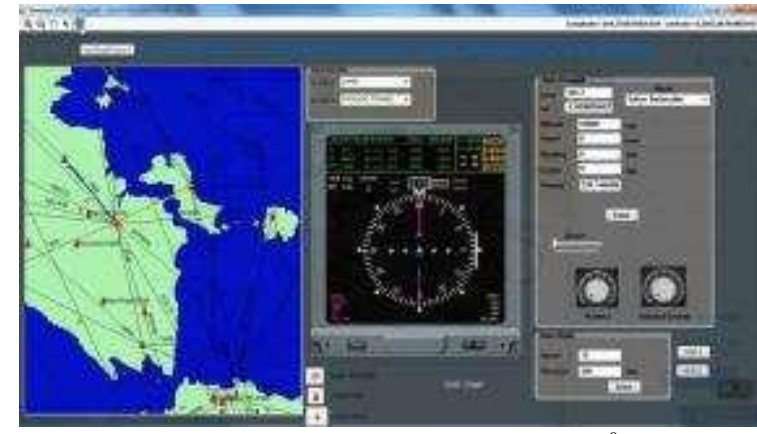

Gbr. 8 Dari Sultan M Badaruddin dengan heading $0^{0}$ dengan VOR JMB dan PKP

Hasil perhitungan perangkat lunak yang dikembangkan dengan heading pesawat $65^{\circ}$ menghasilkan perhitungan bearing antara pesawat terbang dengan JMB adalah $319^{\circ}$ supaya jarum deviasi tepat ditengah dengan course $140^{\circ}$ Visualisasi HSI dari perangkat lunak simulasi dibandingkan dengan perangkat lunak Garmin Integrated Flight Deck Trainer seperti pada gambar berikut,

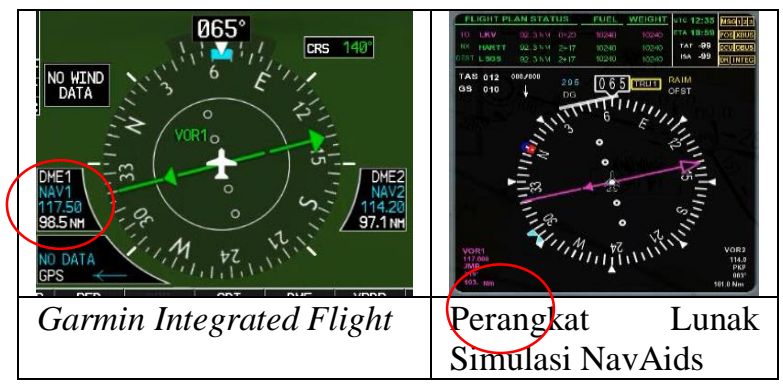

Gbr. 9 Visualisasi HSI Terhadap JMB

Jarak pesawat terbang dengan JMB hasil Garmin 98.5 Nm sementara dengan perangkat lunak simulasi navaids $103 \mathrm{Nm}$. Pengujian terhadap VOR PKP dengan heading pesawat $65^{\circ}$ menghasilkan perhitungan bearing antara pesawat terbang dengan PKP adalah $63^{0}$ supaya jarum deviasi tepat ditengah dengan course $242^{\circ}$. Visualisasi HSI dari perangkat lunak simulasi dibandingkan dengan perangkat lunak Garmin Integrated Flight Deck Trainer seperti pada gambar berikut.

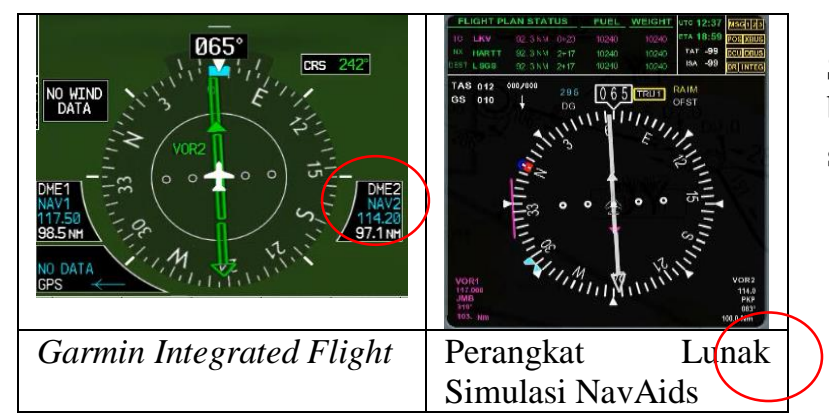

Gbr 10. Visualisasi HSI Terhadap PKP

Jarak pesawat terbang dengan PKP hasil Garmin 97.1 Nm sementara dengan perangkat lunak simulasi navaids $101 \mathrm{Nm}$.
Pengujian NDB dilakukan dari Sultan Badaruddin dengan mengambil arah NX NDB (Jambi NDB) dan OI NDB (Pangkal Pinang NDB).

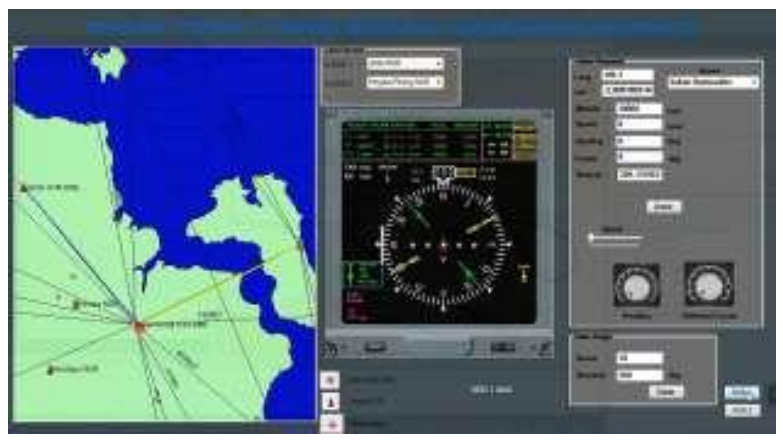

Gbr.11 Dari Sultan M Badaruddin dengan heading $0^{0}$ dengan NDB NX dan OI

Hasil visualisasi dari perangkat lunak yang dikembangkan perhitungan bearing, jarak dan keterangan dari NDB. bearing dan jarak hasil perhitungan divalidasi dengan menggunakan perangkat lunak Map Source Version 6.16.3 Garmin Ltd.

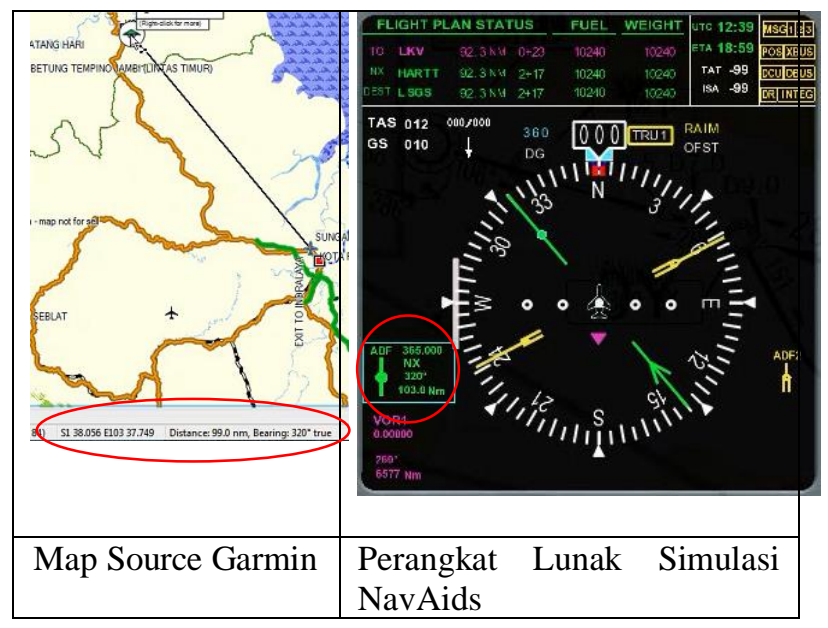

Gbr. 12 Dari Sultan M Badaruddin dengan heading $0^{0}$ dengan NDB NX

Hasil validasi perhitungan jarak antara bandara Sultan Badaruddin dengan NDB NX $99 \mathrm{~nm}$, dengan bearing $320^{\circ}$. Perhitungan dengan perangkat lunak simulasi jarak $103 \mathrm{~nm}$ bearing $320^{\circ}$. 


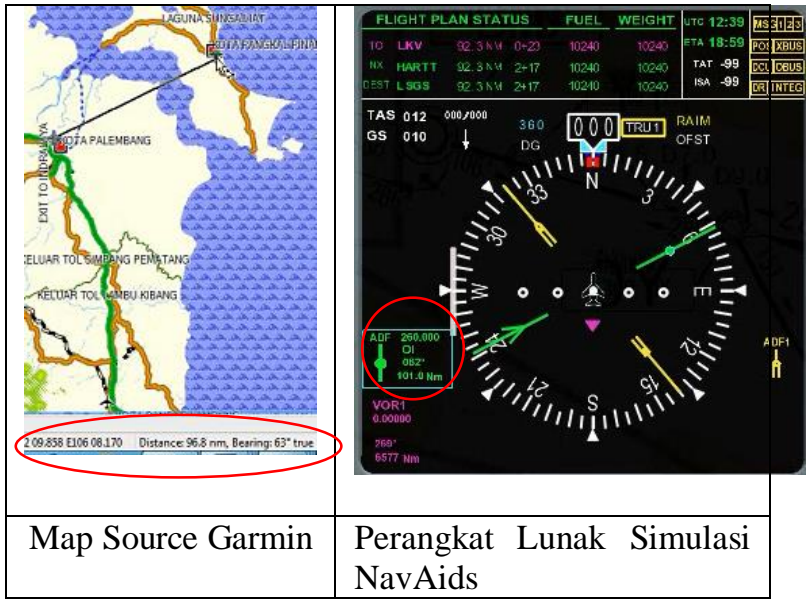

Gbr. 13 Dari Sultan M Badaruddin dengan heading $0^{0}$ dengan NDB OI

Hasil validasi perhitungan jarak antara bandara Sultan Badaruddin dengan NDB OI $96.8 \mathrm{~nm}$, dengan bearing $62^{\circ}$. Perhitungan dengan perangkat lunak simulasi jarak 101. $\mathrm{nm}$ bearing $62^{\circ}$.

\section{KESIMPULAN}

Setelah melakukan pengembangan perangkat lunak simulasi pesawat mendekati navaids, kemudian membandingkan hasil pengukuran dengan perangkat lunak lain yang ada dapat ditunjukkan bahwa algoritma maupun formula untuk perhitungan menunjukkan hasil yang sama dengan perangkat lunak Garmin Integrated Flight dan Map Source Garmin. Demikian juga instrumen HSI yang digunakan nilai yang ditunjukkan pada jarum VOR dan NDB menunjukkan nilai seperti dalam perhitungan.

\section{UCAPAN TERIMA KASIH}

Terima kasih sebesar-besarnya pada Kementerian Riset dan Teknologi Republik Indonesia yang telah berkenan memberikan dana melalui Penelitian Dosen Pemula. Terima kasih juga pada PT. Dirgantara Indonesia tempat penulis mengabdi selama 29 tahun. Tak lupa terima kasih pada pengelola Journal of Computer Engineering, System and Science atas dimuatnya tulisan ini.

\section{REFERENSI}

[1] Aminarno Budi Pradana, "Navigasi berbasis kinerja performance based navigation PNB perwujudan dari operasi penerbangan yang efektif, efisien dan cocok untuk wilayah indonesia," J. Aviasi Langit Biru, 2011.

[2] N. W. Sari and B. Yulianti, “Analisa Fungsi T-DME Sebagai Pengganti Fungsi Outer Marker Runway O7 L Bandara Soekarno Hatta," pp. 49-54.

[3] Soebroto, R. Pugirkhan Yasin,"Analisis-Kebutuhan-TeknisiDivisi-Teknik-Rambu-Udara-di-Tinjau-dari-Manajemen-

Perawatan-di-Bandara-Sotta(1)", J: Jurnal Ilmiah Langit Biru, 2009, Volume 2 Nomor 5

[4] D. Classe, "DP _ 0001 - Digital Pack I Interface Control Document," pp. 1-28, 2007.

[5] Williams,Ed, 2015, Aviation Formulary V1.46,https://edwilliams.org/avform.htm

[6] GL STUDIO, GlsPlayer 4.0.9.0, User's Manual Version 4.0.9.0.a Document Number GLSPLYR-0001 rev

[7] Ariawan D Rachmanto, Iswanto, "Simulator Pesawat Melewati VHF Omnidirectional Radio Range (VOR)," $J$. Teknologi Kedirgantaraan, 2020,. doi: 10.35894/jtk.v5i1.422.

[8] Flight Planner Route Generator https://flightplandatabase.com/planner\#from=WICC\&to=WA RR

[9] PT Dirgantara Indonesia 2008 Software Design Description of OGNT Server For Tentera Udara Diraja Malaysia (TUDM) Document No 35/NTM1/NT1100/08/008

[10] PT. Dirgantara Indonesia. 2009. Syllabus and Study Guide Trainee and Instructor Guide.

[11] Visual Flight Rules, Fadjar Nugroho 11 April 2008, http://www.ilmuterbang.com/artikel-mainmenu-29/teoripenerbangan-mainmenu-68/41-pengetahuan-umumpenerbangan/65-visual-flight-rules

[12] SUSANTO,ARIP, 2015, Navigasi Udara, http://www.aripsusanto.com/p/navigasi-udara.html 